\title{
Redaktionelt forord
}

Kære læser

Velkommen til årets tredje nummer af Samfundslederskab i Skandinavien (SIS), årgang 34.

Fokus \& Forum i dette nummer tager med en direkte beskrivelse af de oplevede organisatoriske problemer på Nordsjællands hospitals akutmodtagelse afsæt i sundhedsvæsenets problemer.

Sundhedsvæsenets udfordringer følges op af nummerets første artikel, der med titlen "Sundhedsplatformen i modvind: En analyse af aktørernes teknologiforståelser i danske medier" belyser implementeringen af Sundhedsplatformen i de to sjællandske regioner. Artiklen er skrevet af Jeppe Agger Nielsen, der er ph.d. og professor ved Aalborg Universitet og Ulrik Bisgaard Ulsrod Røhl, der ph.d.-stipendiat samme sted.

Den anden artikel i dette nummer hedder "REFORMulering - manipulation eller metastyre?” og er en caseanalyse af reformarbejdet på folkeskoleområdet i en dansk kommune. Den er forfattet af Gitte Miller Balslev, der er post.doc., og Peter Henrik Raae, der er lektor emeritus. Begge er tilknyttet Institut for Kulturvidenskaber ved Syddansk Universitet.

Den tredje artikel hedder "Styring i spændingsfeltet mellem vilde problemer og stramme budgetter”. Den er skrevet af Per Nikolaj Bükh, der er ph.d. og professor ved Aalborg Universitet og Anne Kirstine Svanholt, der er cand.soc. fra Aalborg Universitet og afdelingsleder ved Socialforvaltningen i Københavns Kommune.

Ud over artiklerne kan du finde omtaler af kommende artikler, samt orientering om formålet og idégrundlaget bag SIS, tidsskriftets manuskriptvejledning, m.v.

De bedste hilsener

Preben Melander

Ansvarshavende redaktør

Professor emeritus ved CBS 